the record. It would be interesting to have this accurately stated, and more widely published.

At Bangalore, in the Mysore Province, I once registere an inch and a quarter in twenty minutes ; and seven and eight, and more inches have been occasionally gauged during a heavy twenty-four hours' fall, notably so in 1856 , when disastrous floods occurred. Somewhere about that period a most extraordinary fall of rain occurred at Madras. I regret that I have not the record by me, but $I$ am right in saying that more than twenty. three inches fell in twenty-four hours! and that more than seven inches fell within six hours! This was gauged at the Madras Observatory, and registered every hour ; the statement can therefore be easily corroborated by a reference to the superintendent at that place. A coffee planter on the western Ghauts of Mysore

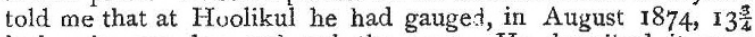
inches in one day, and $10 \frac{1}{4}$ the next. He described it as a sullen, intermittent, continuous downpour, the monotony of which was very depressing. At Mahableshwar, on the same line of Ghauts, the average fall is 240 inches, chiefly in the four or five months, from May to September inclusive ; while at the Cherrapoonji Hills, not very far from Calcutta, the average fall is over 600 inches, or (say) seventeen yards of rain! My notes are in a book that I left in India, but I am within the mark in what has been stated above.

The meteorology of India would furnish many startling incidents. It has not hitherto been sufficiently attended to, or recorded, and much valuable time has been allowed (like the rainfall) to run by; but attention is now, I believe, being paid to its systematic registry, and to the publication of accurate results. I have some interesting records, however, of the Province of Myscre, which I would gladly place at your disposal should you desire to have them.

J. PUCKLE

\section{A New Palmistry}

IT is the old story-" In striving to be concise, I have become obscure." If Mr. Mott will refer to my abstract of Prof. Ecker's paper, he will find directions as to procedure, very briefly stated, I will grant; for I, and others too, more competent to judge than myself, had no idea that the subject would attract the attention which it has done. At Mr. Mott's desire, however, I give lim a literal translation of Prof. Ecker's directions (op. cit. P. 73) in full :-

"With regard to the method of measurement on living individuals, I will merely remark that the hand must be simply laid, with the fingers closed together, upon a board or a piece of paper, upon which a well-defined perpendicular line has been drawn. With this latter the axis of the middle finger and its metacarpal bone is made precisely to coincide. Every lateral movement of the middle finger naturally alters also the position of the other fingers, and every movement of the fingers upon the metacarpal bones towards the pollex turns to the advantage of the position of the index, while that toward the little-finger-edge of the hand to the advantage of that of the ring-finger. The tips of the fingers (without nails $d$ la Chtnois) are then outlined with a pencil, halved longitudinally ; its cut surface being applied against them."

John C. Galton

$$
\text { Nov. } 29
$$

I IFAVE made a number "of determinations of the relative lengths of the "index" and "ring" fingers of both hands, the results of which, I think, very decidedly show that there is a great dissimilarity between the two hands. The hands of twentytwo persons were examined; in ten there was similarity between the hands as regards the relative lengths of the two fingers in question; in twelve there was dissimilarity. In the case of eight question; in " was longer than the "index ;" in one case the "index" was the longer, and in the remaining instance the two fingers were of equal length. Of the twelve cases which exhibited dissimilarity, six had the "ring" longer than the "index" in the left hand, and five in the right hand; four had the "index" longer than the "ring" in the left hand, and in three the same reiation existed in the right hand.

M. M. Pattison Muir

The Owens College, Manchester, Nov. 27

\section{Faye on the Laws of Storms}

M. FAYE's paper on cyclones and waterspouts, of which you have lately published a full abstract, seems very unsatisfactory. The statement in NATURE, vol. xii. p. 4OI, of the laws of the cy- clone's motion is no doubt true, but it is avowedly not original. But the succeeding parts, where the dynamics of the subject are treated of, cannot be sufficient-I think I may say cannot be sound-because they take no account of the very remarkable facts of the geographical distribation of cyclones. If M. Faye's theory were true and complete, cyclones ought to be equally common in all equatorial and tropical regions, except perhsps that they ought to be commonest in the hottest parts. So far is this from being the case, that they are strictly local phenomena. They are formed in the West Indian seas, but not in the South Atlantic; in the Indian Ocean, both north and south of the equator, hut much oftener on the eastern than on the western side of India; and, I believe, off the coast of Calif urnia, but not that of Peru. Their periodicity is equally remarkahle. In the West Indian and in the Chinese seas they occur chiefly at the end of summer, but in the Bay of Bengal atter the equinoxes.

All these facts point to the origin of the cyclone, not, as M. Faye seems to think, in eddies formed in the upper currents of the atmosphere-how could eddies be formed in currents so totally free from obstructions?-but in eddies formed by the meeting and conflict of the two trade-winds where one of them is drawn across the equator. This hypothesis agrees with observation, and harmonises all the geographical facts relating to cyclones.

This simple and true theory is stated in a paper on the Law of Storms by Prof. Maury, in NATURE of June 12, I9, and 26 , 1873. It had previously been stated for the Bay of Bengal, as the result of an examination of particular storms, by $\mathrm{Mr}$. Meldrum, in a paper read before the Meteorological Society of Mauritius, and reported in NATURE, vol. ii. p. I5I ; and a letter of mine in NATURE, vol. iv. p. 305 , maintained the probability of all cyclones so originating.

I think M. Faye is as unsatisfactory on waterspouts as on cyclones, I hope to follow this by a letter on waterspouts.

Oid Forge, Dunmurry, Co. Antrim, Nov, I JOSEPH JOHN MURPHY

\section{OUR ASTRONOMICAL COLUMN}

SATELLITES OF URANUS,-There are many amateurs in this country who possess instruments quite competent to show the two larger or exterior satellites of the planet Uranus, With the view to facilitate the identification of these objects, their angles of position and distances from the centre of Uranus are given below for I4 $\mathrm{a}$. Greenwich mean time for the last ten days of the present year, with the intention of continuing them while the planet is most favourably placed for observation as regards position and distance from the moon's place. They are deduced from the very converient tables appended by Prof. Newcomb to his discussion of the observations of the satellites with the 26 inch equatorial at Washington, forming Appendix I. to the Washington Observations for I873:-

\begin{tabular}{|c|c|c|c|c|c|c|c|c|c|}
\hline G M. & & & TTANIA. & & & & & ERON. & \\
\hline $19 \ldots$ & Pos. & $48 \cdot 0$ & Dist. & 20.8 & $\ldots$ & Pos. & $64 \cdot 2$ & Dist. & 23 \\
\hline $20 \ldots$ & , & $18: 3$ & " & $32 \cdot 3$ & $\cdots$ & $"$ & 33.8 & , & \\
\hline $21 \ldots$ & ", & $359^{\circ} 6$ & ," & $32 \cdot 1$ & $\ldots$ & " & 18.1 & $"$ & \\
\hline $22 \ldots$ & " & 3292 & ," & 20.5 & $\ldots$ & ", & $6 \cdot 1$ & $"$ & \\
\hline $23 \ldots$ & ," & $249^{\circ} 6$ & , & 16.6 & $\cdots$ & ," & $35^{2} 9$ & , & \\
\hline $24 \ldots$ & $"$ & $206 \cdot I$ & ", & $29 \cdot 3$ & $\ldots$ & ", & 3314 & $"$ & \\
\hline $25 \ldots$ & $"$ & 186.4 & ", & 33.9 & $\cdots$ & " & $285^{\circ} 2$ & ", & \\
\hline $26 \quad$. & , & 163.4 & ," & 254 & $\ldots$ & ," & 2334 & $"$ & \\
\hline $27 \ldots$ & , & 100.8 & $"$ & 149 & $\ldots$ & ", & 208.8 &, & \\
\hline $28 \ldots$ & ", & $3^{6 \cdot 2}$ & " & $25^{\circ} \mathrm{O}$ & $\ldots$ & $"$ & 1947 & ", & \\
\hline $29 \quad$. & ", & 129 & ", & 339 & $\cdots$ & ", & 182.9 & $"$ & \\
\hline $30 \ldots$ & ", & $353^{\prime 2}$ & ", & 29.7 & $\cdots$ & ", & 168.4 & " & \\
\hline $3 \mathbf{I} \ldots$ & ", & & ", & $17^{\circ} \mathrm{O}$ & $\cdots$ & , & 14222 & , & \\
\hline
\end{tabular}

The above angles are reckoned as is usual in measures of double stars, i.e., from the $\mathrm{N}$. point round by the east. The apparent diameter of Uranus by the Malta determination of Lassell and Marth will be $3^{\prime \prime} \cdot 87$ on December 25 th. With this value, should it be found more convenient, the arc values may be reduced to distances in diameters of the planet.

The Minor Planets.-No. 156 is announced as having been discovered by Herr Palisa, at Pola, on Nov. 22, in R.A. 2 h. $54 \mathrm{~m}$, , and N.P.D. $70^{\circ} 23^{\prime}$ : it is of 
the twelfth magnitude.-From observations on Nov. 2 and 7 Herr Palisa has calculated circular elements of No. 153, which place the ascending node in longitude $228^{\circ} 3 \mathrm{I}^{\prime}$, with an inclination of $6^{\circ} 57^{\prime}$. The mean diurnal motion assigned on this hypothesis $\left(447^{\prime \prime}\right)$, if it were reliable, would make the period of this planet considerably longer than that of any other member of the group, but it will be necessary to wait till elliptical elements on a fair extent of observation are in our hands, before attributing to No. 153 a revolution so much in excess of the rest.

Publications.-(I) P. A. Hansen. Ueber die Storüngen der Grossen Planeten inbesondere des Fupiter. A posthumous memoir published in vol. xi. of the "Proceedings" of the Mathematical Class of the Royal Saxon Society of Sciences. The analytical developments forming the subject of the first part of this treatise are applied especially to the case of the planet Jupiter; the perturbations of latitude by Saturn, and the perturbations by Uranus, Neptune, Mars, the Earth, Venus, and Mercury are exhibited numerically; and from Herr v. Glasenapp, who was engaged in this part of the work up to the time of Prof. Hansen's decease, may, it is announced, be expected the complete calculation of the perturbations of longitude and radius-vector of Jupiter by Saturn.

(2) J. N. Stockwell. Theory of the Moon's Motion.-This is a republication in an extended form of an investigation which appeared in the Astronomische Nachrichten, Nos. 2,024-2,026, wherein the mathematical developments are given in greater detail, with the addition of those applying to the formulæ for latitude. The author hopes to find time to continue his investigations in the same direction, so as to complete the developments of the perturbations of the moon's motions by means of the differential equations given in this first chapter. In the author's introductory remarks on the labours of those eminent mathematicians who have taken up the lunar theory, in referring to Prof. Hansen, there is no mention of his "Fundamenta nova investigationis orbitæ veræ quam Luna perlustrat," Gotha, 1838; or his "Darlegung der Theoretischen Berechnung der in den Mondtafeln angewandten Storüngen," the first part of which appeared in 1862 , and the second in 1864 .

(3) Dr. Franz Melde. Theorie and Praxis der Astro. nomischen Zeitbestimmung, \&c. (Tübingen, 1875). - The author, Professor in the University of Marburg, explains that in the course of lectures on the determination of time by astronomical observations, he had found the want of a work in which the subject should be treated both in a theoretical and practical point of view, and in the present volume of 500 pages he has presented a very detailed discussion of time-determinations after the methods generally employed. The transit-instrument, its arrangement, mounting, and errors, with the methods of regulating it ; the sextant, more particularly as regards its use for ascertaining time by corresponding altitudes of sun or stars, time by occultations, refraction, aberration, precession, \&c., are explained at length. The volume, it will be seen, is one of a special character, and will be a desirable addition to an astronomical library.

\section{DR. R. VON WILLEMOES-SUHM}

$\mathrm{T} T$ is with the deepest regret that $I$ have to intimate the death of Dr. Rudolf von Willemoes-Suhm, at sea, on our passage from Hawaii to Tahiti. He had not been in his usual robust health for somemonths, having suffered occasionally from indolent boils on different parts of the body. On Sept. 6 he applied to the surgeon for advice. He had had a rather severe shivering fit the day before, and an inflamed spot on the face began to show symptoms of erysipelas. The swelling and inflammation of the face increased during the next week; it extended over the forehead; and the fever and delirium attending erysipelas became more pronounced. On the morning of Sept. I3 he sank into a state of collapse, and died at three o'clock in the afternoon.

This sad occurrence has of course thrown a heavy gloom over our little party. From the commencement of the voyage Dr. v. Willemoes-Suhm devoted himself with unremitting industry and zeal, and in the best possible spirit, to the objects of this expedition. He has already published, in connection with our work, a paper in the Annals and Magazine of Natural History, "On a terrestrial Nemertine from Bermudas;" a long paper in Linnean Proceedings, on the deep-sea Crustacea of the cruise ; "On the development of Umbellularia," in the Annals and Magazine: "On the Development of Lepas fascicularis," a paper sent to the Royal Society from Honolulu; and the notes on Crustacea which have been incorporated from time to time in my letters and reports. He has also written some interesting letters to Prof. von Siebold, describing the general zoological results of the cruise, which have been published in the Zeitschrift fiir Wissenschaftliche Zoologie. He leaves a fine series of drawings, with full descriptions, chiefly illustrating the development of surface Crustacea. For example, the development of species of the genera Euphausia, Sergestes, and Amphion is traced through all its stages. He leaves also an ample official journal in two large volumes. The loss of his valuable assistance in working up the final results of the expedition must, I fear, seriously affect their completeness.

Rudolf von Willemoes-Suhm was a native of SchleswigHolstein; his family now reside in the neighbourhood of Rendsburg, where his father holds a high official appointment. He was about twenty-eight years of age when he died. He studied in the Universities of Göttingen and Bonn; he showed very early a strong taste for natural history in all its branches, and when quite a boy he published papers on the habits of European birds. Shortly after he left the University, he was appointed PrivatDocent in Zoology in the University of Munich, where he was associated with Prof. von Siebold, with whom he was extremely intimate, and whose place he frequently took in the lecture-room when the professor was prevented from teaching by indisposition. In 1868 he visited Italy and made zoological observations at Spezzia. In the summer of 1870 he made a series of observations on various marine animals, Halicryptus, Balanoglossus, \&c. which formed the subject of his thesis on being appointed Privat-Docent in Munich.

In the summer of 1872 he went to the Faeroe Islands. He published some of the results of his investigations there in NATURE and elsewhere, but unfortunately a large series of zoological drawings which represented the greater part of his work was lost in transitu. It was from the accident of his calling upon me in Edinburgh, on his return from Faeroe, while there was still a vacancy on the staff of the Challenger, that he joined the expedition.

Among the more important of his publications are-

"Helminthologische Notizen," I. (Zeitschrift fur Wis. senschaftliche Zoologie, Bd. xix., 3 Heft.) Heft.)

Helminthologische Notizen," II. (Ibid. Bd. xx., I

"Zur Entwickelung von Schistocephalus dimorphus" (Ibid. Bd. xix., 3 Heft.)

"Biologische Beobachtungen über Niedere Thiere" (Leipzig, W. Engelmann, I87I) contains: "On a young calcareous sponge ;" "On the development of an appendiculate Distoma;" "On Balanoglossus kupferi," "On Halicryptus spinulosus;" "On Priapulus caudatus ;" "On the development of some Polychæte Annelids, Etone, Terebella, and Spirorbis;" "On the natural history of Polystoma integerrimum and of P. ocellatum."

Dr. von Willemoes-Suhm was a man of unusual acquirements and culture; besides having a wide and accurate knowledge of the literature of natural science, he 